\title{
The Analysis Effect of Islamicity Performance Index on the Financial Performance of Sharia Commercial Banks in Indonesia
}

\author{
Herman Felani ${ }^{1 *}$, Sri Wahyuni ${ }^{2}$, and Bima Cinintya Pratama ${ }^{3}$
}

\begin{abstract}
This research aims to find empirical effect evidence of Islamicity Performance Index on the financial performance of sharia commercial banks in Indonesia. The index of Islamicity Performance Index used in this research was the profit-sharing ratio, zakat performance ratio, equitable distribution ratio, directors-employees welfare ratio, Islamic income vs non-Islamic income, Islamic investment vs non-Islamic investment. This research used a quantitative approach and used secondary data in the form of sharia commercial bank financial statements for the periode of 2010-2018. The sampling technique in this research used purposive sampling and obtained 13 samples of sharia commercial banks with 117 observational data. The analytical method used in this research is multiple linear regression. Based on the result of this research, it can be concluded that zakat performance ratio, equitable distribution ratio, directorsemployees welfare ratio, Islamic investment vs non-Islamic investment do not affect financial performance. While the profit-sharing ratio, Islamic income vs non-Islamic income have negative effects on financial performance.

Keywords: Financial Performance; Profit Sharing Ratio; Zakat Performing Ratio; Equitable Distribution Ratio; Directors-Employee Welfare Ratio; Islamic Income Vs Non-Islamic Income; Islamic Investment Vs Non-Islamic Investment
\end{abstract}

\section{CITATION:}

Felani, H., Wahyuni, S., \& Pratama, B.C. (2020). The analysis effect of Islamicity performance index on the financial performance of sharia commercial banks in Indonesia. Journal of Economics Research and Social Sciences, 4(2), 129-139.

\section{Introduction}

The development of Islamic banking in Indonesia from year to year always shows an increase, this is in line with the development Islamic business of the world. This also shows that the development of the Islamic economy in Indonesia is getting better, as one of the social activities has shown success in the economic field, the OJK (2017). The development of Islamic economics in Indonesia is identical with the development of Islamic financial institutions, OJK (2017). Based on data sourced from the OJK in 2017 along with an increase in the number of banks and assets, there are many challenges that need to be faced by Islamic banking with the development of technology and science. This requires Islamic banking to continue to innovate to improve performance in order to be able to compete with other banks (OJK, 2017).

Financial performance is one of the fundamental aspects regarding the company's financial condition, for Islamic banking can be analyzed with profitability ratios using the Return on Osset (ROA) measure. 
ROA is used in the measurement of financial performance because ROA is able to measure the effectiveness of management as a whole in the achievement of income by measuring the amount of profits obtained by banks (Khasanah, 2016).

Performance measurements have been carried out among others by, Hameed, Ade, Bakhtiar, Nazli, and Sigit (2004) presents an alternative performance measurement for Islamic banking, namely using the Islamicity performance index. This index aims to determine whether the financial performance of Islamic banking has been carried out in accordance with Islamic principles. Hameed et al., (2004) presents an alternative performance measurement that is the Islamicity performance index. Islamicity performance index is related to organizational performance. That way, it can be seen whether the banking performance that has been carried out in accordance with sharia principles will affect the financial performance of sharia banks.

The components of the Islamicity performance index include profit sharing ratio, zakat performing ratio, equitable distribution ratio, director employee welfare ratio, Islamic income vs. non-Islamic income, Islamic investment vc non-Islamic investment. The higher the Islamicity performance index of a bank, the higher the profitability that will be obtained by the bank. Of the seven ratios on the Islamic performance index, not all are used in this study to measure financial performance. This research only uses profit sharing ratio, zakat performance ratio, equitable distribution ratio, directors-employees welfare ratio, Islamic investment vs. non-Islamic investment ratio and Islamic income vs. non-Islamic income ratio. While the AAOIFI index ratio is not used in this study because the ratio is not yet available in financial statements in Indonesia (Khasanah, 2016). So that these variables cannot be tested in this study.

\section{Literature Review and Hypotheses Development}

According to Anggraini (2012) financial performance is the result of the company's operations which are presented in the form of financial figures that can be compared with the financial results of the previous period or the results of other similar companies. Financial performance is an analysis conducted to see the extent to which a company has carried out using the rules of financial implementation properly and correctly (Fahmi, 2017).

Performance measurement is a periodic determination of the operational effectiveness of an organization, parts of the organization, and its employees based on predetermined goals, standards, and criteria (Mulyadi, 2001). The results of the company's operations are financial transactions expressed in monetary value, so they can be used as material in conducting comparative analyzes. Analysis is carried out to assess the results of operating activities, whether increasing or decreasing, with the analysis of the results of the company's operational activities, management can take the actions needed with these conditions (Anggraini, 2012). 
The company's financial performance can also be measured using financial statement analysis or ratio analysis. Performance measurements carried out every certain time period are very useful to assess the progress that has been achieved by the company and produce information that is very useful for decision making and able to create company value itself, Mulyadi (2001).

According to Jumingan (2006) financial performance is a picture of financial conditions relating to the collection of funds and distribution of funds in a certain period. Usually the financial condition is measured by indicators of capital adequacy, liquidity, and profitability. Adequacy of capital is related to the activities of raising funds and channeling funds. The assessment of liquidity conditions is carried out to determine the ability to meet obligations to depositors, while to determine the ability to generate profits an assessment of the profitability aspect, Brigham and Houston (2001).

Hameed et al. (2004) through their journals have developed an index called the Islamiciy performance index, which is a measure of organizational performance to measure the performance of Islamic financial institutions, by implementing Islamic principles affecting the financial health of Islamic banking in Indonesia. This performance measurement is based on information available in the annual report of Hameed et al. (2004), which consists of:

Profit Sharing Ratio (PSR) is one of the ratios to measure the activities of Islamic banks in channeling financing in the form of profit sharing. One of the main objectives of a Sharia Bank is profit sharing, Khasanah (2016).

Zakat Performance Ratio (ZPR) is a ratio that measures how much zakat is issued by Islamic banks compared to net assets, Aisjah and Hadianto (2013). Zakat is one of the commands in Islam so it must be one of the objectives of sharia accounting. Therefore, the performance of Islamic banking must be based on zakat paid by banks to replace conventional performance indicators namely earnings per share, Listiani et al. (2016).

Equitable Distribution Ratio (EDR) This ratio basically tries to find out how the revenue generated by Islamic banks has been distributed among stakeholders represented by the amount spent on qardh and donations, employee costs and others, Hameed et al., (2004).

Directors Employees Welfare ratio (DEWR) aims to identify how much money is used for director salaries compared to money used for employee welfare, Puspitosari (2016).

Islamic Income Vs Non-Islamic Income (ISIR) is a ratio that compares between halal income with all revenue obtained by Islamic banks as a whole, Khasanah (2016).

Islamic Investment Vs Non-Islamic Investment (IIR) The ratio that compares the halal investment with the total investment made by the bank as a whole is expressed in the form of a ratio between sharia investments and the amount of sharia and non-sharia investments (Hameed, et al., 2004). 
$\boldsymbol{H}_{1}=$ profit sharing ratio positive effect on financial performance .

$\boldsymbol{H}_{\mathbf{2}}=$ zakat performance ratio positive effect on financial performance.

$\boldsymbol{H}_{3}=$ equitable distribution ratio positive effect on financial performance.

$\boldsymbol{H}_{4}=$ directors-employees welfare ratio positive effect on financial performance.

$\boldsymbol{H}_{5}=$ Islamic income vs non-Islamic income ratio positive effect on financial performance.

$\boldsymbol{H}_{6}=$ Islamic investment vs non-Islamic investment ratio positive effect on financial performance.

\section{Research Method}

This type of research is causal comparative. This research is causal, namely an analysis of the relationships between one variable with another variable or how a variable affects other variables (Umar, 2011). The type of research approach used in this study is a quantitative approach, namely research that indirectly retrieves data through intermediary media. This study aims to determine how the influence of independent or independent variables, namely the component of the Islamic performance index to the dependent or dependent variable, namely financial performance (ROA) of Islamic banks. the population chosen by researchers in this study is Islamic commercial banks in Indonesia registered with Bank Indonesia (BI) and the Financial Services Authority (OJK) and have complete financial statements during 2010 - 2018. Data analysis methods in this study use multiple regression analysis, namely the study of the dependence of one dependent variable (bound) with one or more independent variables (free), which aims to predict the population average or the average value of the dependent variable based on the value of a known independent variable, Rosadi (2012).

\section{Result and Discussion}

Normality Test

Based on the results of the normality test shows that the significance value of the normality test to $1-5$ is $<0.05$, this shows that the data are not normally distributed. How to deal with abnormal data can use casewise diagnostic / outlier by removing some data that are considered extreme so that the spread of data becomes normal (Ghozali, 2013). Diagnostic diagnostics have been carried out 6 times and the 6th test shows that the research data is worth 0.200 which indicates that the data is normally distributed because it is above 0.05 . 
Table 1 Normality Test Result

\begin{tabular}{|c|c|c|c|c|c|}
\hline & $\mathbf{N}$ & Sig & Information & Outlier Data & \\
\hline Normality Testing 1 & 117 & 0,000 & Abnormal & Bank BTPN Syariah & 2014 \\
\hline \multirow[t]{4}{*}{ Normality Testing 2} & 116 & 0,000 & Abnormal & Bank Jabar Banten Syariah & 2016 \\
\hline & & & & Bank Jabar Banten Syariah & 2017 \\
\hline & & & & Bank BTPN Syariah & 2017 \\
\hline & & & & Bank BTPN Syariah & 2018 \\
\hline \multirow[t]{2}{*}{ Normality Testing 3} & 112 & 0,000 & Abnormal & Bank Bukopin Syariah & 2016 \\
\hline & & & & Bank Jabar Banten Syariah & 2018 \\
\hline \multirow[t]{4}{*}{ Normality Testing 4} & 110 & 0,000 & Abnormal & Bank Panin Dubai Syariah & 2010 \\
\hline & & & & Bank BTPN Syariah & 2011 \\
\hline & & & & Bank BTPN Syariah & 2013 \\
\hline & & & & Bank Victoria Syariah & 2015 \\
\hline \multirow[t]{5}{*}{ Normality Testing 5} & 106 & 0,003 & Abnormal & Bank BTPN Syariah & 2010 \\
\hline & & & & Bank BTPN Syariah & 2012 \\
\hline & & & & Bank Victoria Syariah & 2014 \\
\hline & & & & Bank Victoria Syariah & 2016 \\
\hline & & & & Bank Bukopin Syariah & 2017 \\
\hline Normality Testing 6 & 101 & 0,200 & Normal & & \\
\hline
\end{tabular}

Multicollinearity Test

Multicollinearity test aims to test whether there is a relationship between several variables or all independent variables in the regression. A good regression model should not occur correlation between independent variables (Ghozali, 2013). Based on the multicollinearity test results it can be concluded that all independent variables in the regression equation model do not occur multicollinearity symptoms.

Table 2 Multicollinearity Test Result

\begin{tabular}{lllll}
\hline \multicolumn{2}{l}{ Model } & \multicolumn{2}{c}{ Colinearity Statistic } \\
Tolerance & VIF & \\
\hline 1 & (Constant) & & & \\
& PSR & 0,890 & 1,123 & Free of Multicollinearity \\
& ZPR & 0,977 & 1,023 & Free of Multicollinearity \\
& EDR & 0,821 & 1,219 & Free of Multicollinearity \\
& DEWR & 0,974 & 1,027 & Free of Multicollinearity \\
& ISIR & 0,946 & 1,057 & Free of Multicollinearity \\
& IIR & 0,781 & 1,280 & Free of Multicollinearity \\
\hline
\end{tabular}

\section{Autocorrelation Test}

The autocorrelation test is used to test whether in a linear regression model there is a correlation between the error of disturbance in period $t$ and error in period $t-1$. A good regression model is free from autocorrelation (Ghozali, 2013).

Table 3 Autocorrelation Test Result

\begin{tabular}{ccccc}
\hline Model & Durbin-Watson & $\mathrm{K}$ & $\mathrm{dU}$ & Information \\
\hline $\mathbf{1}$ & 2,085 & 6 & 1,8033 & Free of Autocorrelation \\
\hline
\end{tabular}

Source : Data processed in 2019 
Data does not occur autocorrelation symptoms if $d u<D W<4-d u$. Based on the results of the output in the table shows $1.8033<2.085<4-1.8033=1.8033<2.085<2.1967$ therefore it can be concluded that the data in this study did not occur autocorrelation symptoms.

Heteroscedasticity Test

Heteroscedasticity test is used to test whether in the regression model used there is an inequality of variance from the residuals of one observation to another (Ghozali, 2013). If the significance value $>0.05$ then the regression model is free from heteroscedasticity symptoms. Heteroscedasticity test results can be seen in the table below which shows there is no heteroscedasticity in this study.

Table 4 Heteroscedasticity Test Result

\begin{tabular}{lll}
\hline Model & Sig. \\
\hline 1 & (Constant) & 0,105 \\
& PSR & 0,590 \\
& ZPR & 0,462 \\
& EDR & 0,898 \\
& DEWR & 0,327 \\
& ISIR & 0,061 \\
& IIR & 0,106 \\
\hline
\end{tabular}

a. Dependent Variabel: HET1

Source: Data processed in 2019

Multiple Linear Analysis Test

Based on the results of the regression analysis above, a regression equation can be arranged as follows:

Table 5 Multiple Linear Analysis Test Result

\begin{tabular}{|c|c|c|c|}
\hline Variabel & B & $\mathrm{t}$ & Sig. \\
\hline PSR & $-0,006$ & $-4,129$ & 0,000 \\
\hline ZPR & $-0,072$ & $-0,093$ & 0,926 \\
\hline EDR & 0,000001887 & 0,022 & 0,983 \\
\hline DEWR & 0,00002917 & 1,040 & 0,301 \\
\hline IsIR & $-0,020$ & $-9,763$ & 0,000 \\
\hline IIR & 0,002 & 0,550 & 0,583 \\
\hline
\end{tabular}

ROA $=0,029-0,006$ PSR $-0,072$ ZPR $+0,000001887$ EDR + 0,00002917 DEWR $-0,020$ ISIR + 0,002 IIR + e

$\alpha=$ The constant value $(\alpha)$ indicates the positive value of the independent variable (Profit Sharing ratio, Zakat Performance Ratio, Equitable Distribution Ratio, Directors-employees Welfare Ratio, Islamic Income vs. Non-Islamic Income, Islamic 
Investment vs. Non-Islamic Investment). If the independent variable increases or influences in one unit, the financial performance variable will increase.

$\beta 1=$ The regression coefficient value of the Profit-Sharing Ratio variable shows a Negative value of -0.006 that each increase in Profit Sharing Ratio of 1 unit does not cause financial performance to decrease by 0.006 units assuming the other variables are fixed.

$\beta 2=$ The regression coefficient value of the Zakat Performance Ratio variable shows a Negative value of -0.072 that for each increase in Zakat Performance Ratio of 1 unit the financial performance decreases by 0.072 units assuming the other variables are fixed.

$\beta 3=$ The regression coefficient value of the Equitable Distribution Ratio variable shows a positive value of 0.000001887 that each increase in the Equitable Distribution Ratio of 1 unit causes the financial performance to increase by 0.000001887 units assuming the other variables remain constant.

$\beta 4=$ The regression coefficient of the Directors-employee Welfare Ratio variable shows a positive value of 0.00002917 that each increase in Directors-employee Welfare Ratio of 1 unit causes the financial performance to increase by 0.00002917 units assuming other variables remain constant.

$\beta 5=$ The regression coefficient value of the Islamic Income vs. non-Islamic Income variable shows a negative value of -0.020 that every increase in Islamic Income vs Non-Islamic Income of 1 unit will cause financial performance to decrease by 0.020 units assuming the other variables remain.

$\beta 6=$ The regression coefficient value of the Islamic Investment vs. non-Islamic Investment variable shows a positive value of 0.002 that every increase of Islamic Investment vs. Non-Islamic Investment by 1 unit causes the financial performance to increase by 0.002 units assuming the other variables are fixed.

$\mathrm{e} \quad=$ Standard Error (error).

\section{Determination Coefficient Test}

Based on the SPSS output, it can be seen that the adjusted $R$ square value of 0.535 means that $53.5 \%$ of the ROA variable can be explained by the PSR, ZPR, EDR, DEWR, IsIR, IIR variables while the remaining $46.5 \%$ is explained by other variables outside the regression model in this study such as company age and company size (Dewanata, Hamidah, \& Ahmad, 2016).

Table 6 Determination Coefficient Test Result

\begin{tabular}{ccc}
\hline$R$ & $R$ Square & Adjust $R$ Square \\
\hline 0,750 & 0,563 & 0,535 \\
\hline
\end{tabular}


t- Test

\begin{tabular}{lccc} 
t-Test Result & \multicolumn{3}{c}{} \\
\hline \multicolumn{1}{c}{ Variabel } & $\mathrm{B}$ & $\mathrm{t}$ & Sig. \\
\hline PSR & $-0,006$ & $-4,129$ & 0,000 \\
ZPR & $-0,072$ & $-0,093$ & 0,926 \\
EDR & 0,000001887 & 0,022 & 0,983 \\
DEWR & 0,00002917 & 1,040 & 0,301 \\
IsIR & $-0,020$ & $-9,763$ & 0,000 \\
IIR & 0,002 & 0,550 & 0,583
\end{tabular}

First Hypothesis

The t-test results showed a regression coefficient of -0.006 with a negative direction having a significant value of $0,000<0.05$. This shows that the independent variable in this regression model, namely profit-sharing ratio, has a negative effect on financial performance (ROA). With a tcount $(-4.129)<\mathrm{t}$-table (1.98326). Based on the results of the statistical analysis above, it can be concluded that the second hypothesis which states that the profit-sharing ratio has a positive effect on financial performance is rejected.

The results of this study indicate that the higher the value of the profit-sharing ratio will cause a decrease in the financial performance of Islamic banks and if the lower the value of profit-sharing ratios will increase the financial performance value of Islamic banks. That is because the profit-sharing ratio is a financing that has a risk that tends to be high and usually is a financing that is less interested (Nurdin \& Suyudi, 2019). Another factor is the amount of financing based on profit sharing distributed by banks is still relatively low so that the contribution of profit from profit sharing financing is not optimal (Dewanata et al, 2016).

\section{Second Hypothesis}

T test results showed that the zakat performance ratio variable obtained a regression coefficient of -0.072 with a negative direction, a significant value of 0.926 was greater than 0.05 and a calculated value of -0.093 . The value of t-count $(-0.093)<t$-table (1.98326) indicates that the zakat performance ratio does not affect the financial performance that is proxied by ROA. Thus, the third hypothesis which states zakat performance ratio has a positive effect on financial performance which is proxied by ROA is rejected.

The results of this study indicate that changes in the value of the zakat performance ratio do not affect financial performance that is proxied by ROA in Islamic commercial banks. This is because there are other factors that influence financial performance besides zakat. This happens because the distribution of zakat by Islamic banks is not balanced with the acquisition of profits in its use, so it does not have enough power to influence the financial performance of Islamic banks. 
Third Hypothesis

T test results showed that the equitable distribution ratio variable obtained a regression coefficient of -0.000001887 with a negative direction, a significant value of 0.983 over 0.05 and a calculated value of 0.022 . The value of $t$-count $(0.022)<t$-table $(1.98326)$ indicates that the equitable distribution ratio does not affect the financial performance that is proxied by ROA. Thus, the fourth hypothesis which states that the equitable distribution ratio has a positive effect on financial performance that is proxied by ROA is rejected.

The results of this study indicate that no matter how large the equitable distribution ratio (EDR) value will not affect the value of financial performance. This is due to the small utilization of the distribution of income made by Islamic commercial banks to stakeholders. So, it does not have enough power to influence financial performance.

\section{Fourth Hypothesis}

$T$ test results showed that the variable directors-employees welfare ratio (DEWR) obtained a regression coefficient of 0.00002917 with a positive direction, a significant value of 0.301 greater than 0.05 and a calculated value of 1.040 . The value of $t$-count $(1.040)<$ t-table $(1.98326)$ indicates that the DEWR has no effect on financial performance proxied by ROA, so the fifth hypothesis stating that the directorsemployees welfare ratio has a positive effect on financial performance is rejected.

The results of this study indicate that any directors-employees welfare ratio determined by Islamic commercial banks does not affect the financial performance (ROA) of Islamic commercial banks. This is because there is a gap in the director's salary with employee salaries so that the value does not affect the financial performance. Therefore, justice must be upheld in Islamic institutions to reduce the gap between leaders and employees. Islamic commercial banks are required to conduct an evaluation so that the average salary of directors and employees is not too high and does not cause problems in the future (Khasanah, 2016).

\section{Fifth Hypothesis}

T test results show that the Islamic income vs. non-Islamic income ratio variables obtain a regression coefficient of -0.020 with a negative direction, a significant value of 0,000 is less than 0.05 and a calculated value of -9.763 . This shows that the independent variable in this regression model that is Islamic income vs. non-Islamic income has a negative effect on financial performance (ROA). With a tcount (-9.763) <ttable (1.98326). By using significance, it can be concluded that the sixth hypothesis which states that Islamic income vs. non-Islamic income has a positive effect on financial performance is rejected.

The results of this study indicate that the higher the value of Islamic income vs. nonIslamic income, it will reduce the financial performance of Islamic banks and the lower the value of Islamic income vs. non-Islamic income, it will increase the value of financial 
performance. This is due to the high halal income obtained by Islamic commercial banks by $99 \%$ compared to halal and non-halal income so that it will continue to produce a fairly high value of Islamic income vs. non-Islamic income (Fatmasari \& Kholmi, 2018), this is not balanced by the value ROA where the value of profit before tax is lower than the total assets.

\section{Sixth Hypothesis}

$T$ test results showed that the Islamic investment vs. non-Islamic investment variable ratio obtained a regression coefficient of 0.002 with a positive direction, a significant value of 0.624 was greater than 0.05 and a calculated value of 0.492 . The value of $t-$ count $(0.492)<$ ttable (1.98326) indicates that the Islamic investment vs. non-Islamic investment ratio does not affect the financial performance that is proxied by ROA. Thus, the seventh hypothesis which states that the Islamic investment variable vs. non-Islamic investment variable ratio has a positive effect on financial performance which is proxied by ROA is rejected.

The results of this study indicate that regardless of the value of Islamic investment vs. non-Islamic investment ratio will not affect the value of financial performance. This happens because the Islamic investment vs. non-Islamic investment ratio does not have enough power to influence financial performance.

\section{Conclusion}

Based on the analysis that has been done, the following conclusions can be drawn: Profit sharing ratio has a negative effect on financial performance which is proxied by ROA. Zakat performance ratio has no effect on financial performance that is proxied by ROA. Equitable distribution ratio has no effect on financial performance that is proxied by ROA. Directors-employees welfare ratio has no effect on financial performance that is proxied by ROA. Islamic income vs non-Islamic income has a negative effect on financial performance which is proxied by ROA. Islamic investment vs non-Islamic investment has no effect on financial performance that is proxied by ROA.

Limitations in this study are as follows: Financial performance measurement only uses one of the profitability ratios, namely return on assets (ROA), so it does not explain the other financial ratios, for example, ROE, ROI, NPM. Types of Islamic banking that can be used as populations and samples are limited to Islamic commercial banks, so they are less representative of the condition of Islamic banking in Indonesia.

Based on the results of the research that has been stated, the following suggestions can be given: For further researchers, it is better to add a proxy for financial performance, not just using a return on asset (ROA) measure. For further researchers should increase the population and sample, so that research can be generalized properly. Like, Sharia Business Units (UUS), and Islamic People's Financing Banks (BPRS). 


\section{References}

Aisjah, S., \& Hadianto, A. E. (2013). Performance based Islamic performance index (Study on the Bank Muamalat Indonesia and Bank Syariah Mandiri. Asia Pacific Management and Business Application, 2(2), 98-110. https://doi.org/10.21776/ub.apmba.2013.002.02.2

Anggraini. (2012). Analisis perbandingan kinerja keuangan perbankan syariah dengan perbankan konvensional periode 2002-2011. Skripsi. Universitas Hasanuddin.

Brigham, E.F. \& Houtson, J.F. (2001). Manajemen Kenangan. (Dodo Subarno dan Hermawan Wibowo. Terjemahan). Jakarta: Erlangga.

Dewanata, P., Hamidah, H., \& Ahmad, G. N. (2016). The effect of intellectual capital and islamicity performance index to the performance of Islamic Bank in Indonesia 20102014 Periods. JRMSI - Jurnal Riset Manajemen Sains Indonesia, 7(2), 259-278. https://doi.org/10.21009/JRMSI.007.2.04

Fatmasari, R., \& Kholmi, M. (2018). analisis kinerja keuangan perbankan syariah dengan pendekatan islamicity performance index pada perbankan syariah di Indonesia. Jurnal Akademi Akuntansi, 1(1). https://doi.org/10.22219/jaa.v1i1.6940

Ghozali, I. (2013). Aplikasi analisis multivariate dengan program IBM SPSS 19. Semarang. Badan penerbit UNDIP.

Hameed, S., Ade, W., Bakhtiar, A., Nazli, dan Sigit, P. (2004). Alternative disclosure dan performance for Islamic Bank's. Saudi Arabia. Dahran.

Jumingan. (2006). Analisis laporan kenangan. Jakarta: Bumi Aksara.

Khasanah, A. N. (2016). Pengaruh intellectual capital dan islamicity performance index terhadap kinerja keuangan perbankan syariah di INDONESIA. Nominal, Barometer Riset Akuntansi Dan Manajemen, 5(1). https://doi.org/10.21831/nominal.v5i1.11473

Listiani, Y. U., Nurhasanah, N., \& Bayuni, E. M. (2016). Pengaruh islamicity performance index terhadap profitabilitas bank jabar banten syariah periode 2011-2014. Prosiding Keuangan \& Perbankan Syariah, 574-578. http://dx.doi.org/10.29313/syariah.v0i0.3423

Mulyadi. (2001). Akuntansi pembiayaan mudharabah dan rekayasa, edisi ketiga, STIE YKPN, Yogyakarta.

Nurdin, S., Suyudi, M. (2019). Pengaruh intellectual capital dan islamicity performance index terhadap kinerja keuangan perbankan syariah di Indonesia. Jurnal Akuntansi multi dimensi, 2(2). http://dx.doi.org/10.96964/jamdi.v2i1.118

Otoritas Jasa Keuangan. (2017). Laporan Perkembangan Keuangan Syariah.

Puspitosari, I. (2017). Modal intelektual dan kinerja keuangan dengan menggunakan islamicity performance index pada umum syariah. HUNAF A: Jurnal Studia Islamika, 13(2), 248-270. https://doi.org/10.24239/isi.v13i2.439.248-270

Rosadi, D. (2012). Ekonometrika dan Analisis Runtun Waktu Terapan dengan Eviews. Yogyakarta: Andi Offset. 